\title{
E-learning in Pathology Education: A Narrative Review and Personal Perspective
}

\author{
Author: \\ Maheswari Mukherjee \\ Cytotechnology Education, College of Allied Health Professions, University of \\ Nebraska Medical Center, Omaha, Nebraska, USA \\ *Correspondence to mmukherj@unmc.edu \\ Disclosure: $\quad$ The author has declared no conflicts of interest. \\ Received: \\ 15.10.2018 \\ Accepted: \\ 24.06.2019 \\ Keywords: \\ Education, E-learning, pathology. \\ Citation: \\ EMJ Innov. 2020;4[1]:48-56.
}

\section{Abstract}

In recent years, E-learning, also known as web-based learning, online learning, computer-assisted instruction, or internet-based learning, has been used frequently in healthcare education programmes. E-Learning has played a significant role in the author's cytotechnology programme by providing online distance education to multiple sites nationally, and soon internationally.

Although many papers currently exist regarding E-learning, the literature lacks review papers on E-learning in pathology education. The objectives of this paper, therefore, are to provide a narrative review of the approaches used in incorporating E-learning in pathology education, and to provide a faculty member's perspective of experiences, lessons learned in developing E-learning modules, and suggestions to future faculty developers of E-learning modules.

For the purpose of this review, PubMed and Google Scholar search engines were used to search articles published between the years 2008 and 2018. Any review articles and articles from proceedings were not selected for this review. The search resulted in 17 articles that met the criteria for further review. The reviewed literature showed that E-learning has been widely used in pathology education. There is, however, a lack of studies evaluating pre and post-test scores and the cost effectiveness of E-learning technologies.

\section{INTRODUCTION}

In recent years, E-learning, also known as webbased learning, online learning, computer-assisted instruction, or internet-based learning, has been used frequently to train healthcare practitioners, including those in nursing and radiology.,2 E-Learning has played a significant role in the author's cytotechnology (CT) programme by providing online distance education to multiple sites nationally, with plans for international

implementation as well. This CT programme is a post-baccalaureate certificate programme with a 12-month curriculum that provides students with entry-level competencies as cytotechnologists. The class size ranges from 4 to 12 participants, and is currently the only programme in the nation that offers synchronous distance education, serving 4 satellite sites.

This CT programme has incorporated E-learning slowly and steadily for the past few years, 
with the significant step of incorporation of a virtual microscopy (VM) system. E-learning started with the building of a VM database of cytopathology digital images scanned using iScan Coreo Au scanner (Ventana, Arizona, USA) in mScope software (Aurora Interactive, Montreal, Quebec, Canada). Currently, the author has $>3,000$ digitised images that are used to create annotated teaching images, unannotated daily screening practice images, and screening test images. The digitised images are also used to create virtual scope session videos to mimic multihead microscope sessions. These videos are made available to the students on the course management system.

After it was determined that the students were able to learn cytomorphology using VM and apply their learning to screening glass slides with a microscope, ${ }^{3}$ the author aimed to reduce or eliminate the need for additional in-person training in the cytology laboratory by adding E-learning modules to the current online curriculum. With internal funding received from the author's institution, the digitised images were used to develop E-learning modules. At this time, nine E-learning modules have been developed using Articulate 360 (Articulate Global, Inc., New York City, New York, USA) software. The E-learning modules include the title, specific objectives, video clips of the content, and interactive self-assessment questions with feedback. The perceptions of the CT students were assessed regarding the content of the E-learning modules and the perceived influence of the E-learning modules on their performance during clinical rotations. Students responded positively to the statements regarding the quality of the video and audio, duration, navigation, and the materials presented. Most of the students also responded positively, stating that the E-learning modules better prepared them for their role during clinical rotations and recommended developing more E-learning modules for cytology courses in the future. ${ }^{4}$ With the positive results received from the students, more E-learning modules are currently being developed. The programme, however, is yet to evaluate the objective outcomes of students' learning influenced by E-learning modules. It is crucial to determine the role of E-learning modules in students' education, which can be measured by comparing the pre and post-test scores.
The author's long-term goal is to statistically prove the effectiveness of E-learning modules in students' education in this CT programme. The short duration as well as small class size of the programme, however, makes it difficult to statistically measure the objective outcomes.

Although many research papers have been published regarding E-learning in the training of healthcare professionals in sectors such as radiology, pharmacy, and nursing, the literature lacks review papers regarding the effectiveness of E-learning in specific healthcare professional educational training. As a faculty member who has had positive as well as challenging experiences in developing E-learning modules, the current paper was the result of the author's own personal curiosity to know how other educational programmes have used E-learning for pathology education. The primary objective of this review was to identify the approaches to measure the objective outcomes of students' learning influenced by E-learning modules in pathology education. The secondary objectives were to provide a narrative review of the approaches used to incorporate E-learning in pathology education, with a particular interest in describing the purpose of that incorporation, how E-learning has been incorporated, what types of outcome measures have been used to evaluate the effect of E-learning in pathology education, and a faculty member's perspective of experiences and lessons learned in developing E-learning modules with suggestions for future development of E-learning modules.

\section{METHODS}

For the purpose of this review, PubMed and Google Scholar search engines were used to search articles published between the years 2008 and 2018. The keywords used to search the articles were "E-Learning", "E-learning", "eLearning", "e-learning", "Web-based”, "online”, and "pathology". This search resulted in 26 articles. Seven articles, however, did not report E-learning in pathology education, one article was a proceeding, and another article was a review article and therefore all nine articles were excluded from the analysis for this study. The title or the abstract of the articles that contained at least one of the six keywords mentioned 
above and the words "pathology/pathologist", "training", and/or "education" were included for the analysis of this study.

\section{RESULTS}

The search resulted in 17 articles that met the criteria for further review for this paper. ${ }^{5-21}$ Review of the literature led to the arrangement of 3 categories: 1) purpose of incorporating E-learning in pathology education; 2) how E-learning has been incorporated; and 3) outcome measures that were used to evaluate the effects of E-learning in pathology education. The main information gathered from the 17 articles reviewed in this study are summarised in Table 1.

Table 1: A summary of the main information gathered from the 17 articles reviewed in this study.

\begin{tabular}{|c|c|c|c|}
\hline Author, year & Purpose of the study & Type of E-learning & Findings \\
\hline Ariana et al., ${ }^{5} 2016$ & $\begin{array}{l}\text { To determine if blended } \\
\text { learning combining } \\
\text { E-learning with traditional } \\
\text { learning methods of } \\
\text { lectures and tutorials would } \\
\text { improve students' scores } \\
\text { and satisfaction over those } \\
\text { who experienced traditional } \\
\text { learning alone. }\end{array}$ & $\begin{array}{l}\text { Online practical and lecture } \\
\text { notes, digitised slides images } \\
\text { interactive microscopy } \\
\text { section for the students to } \\
\text { review materials and conduct } \\
\text { self-evaluation. }\end{array}$ & $\begin{array}{l}\text { E-learning tools for delivering } \\
\text { pathology instruction can be } \\
\text { an effective supplement for } \\
\text { developing dental students' } \\
\text { competence, confidence, and } \\
\text { satisfaction. }\end{array}$ \\
\hline Klatt, $^{6} 2014$ & $\begin{array}{l}\text { To analyse the usage and } \\
\text { results of web-based } \\
\text { pathology practice } \\
\text { examinations that were } \\
\text { developed to assist } \\
\text { students using formative } \\
\text { assessments of their } \\
\text { knowledge. }\end{array}$ & $\begin{array}{l}\text { Website that provides } \\
\text { pathology images with text } \\
\text { descriptions, along with } \\
\text { examination questions. The } \\
\text { questions provided feedback } \\
\text { for each answer chosen by } \\
\text { the user. The website also } \\
\text { contained timed examinations } \\
\text { to mimic real testing } \\
\text { environment. }\end{array}$ & $\begin{array}{l}\text { A cohort of serious users fully } \\
\text { completing the exams had } \\
\text { sufficient preparation to use } \\
\text { them to support their pathology } \\
\text { education. }\end{array}$ \\
\hline Hosseini et al., 2014 & $\begin{array}{l}\text { To examine the efficiency of } \\
\text { using educational software } \\
\text { in practical oral pathology } \\
\text { scores of dentistry students. }\end{array}$ & $\begin{array}{l}\text { Software (CD-ROM) that } \\
\text { had images of pathology } \\
\text { samples put in appropriate } \\
\text { arrangements. }\end{array}$ & $\begin{array}{l}\text { The mean scores of the students } \\
\text { in the new group were higher } \\
\text { than the traditional group; } \\
\text { however, this difference was } \\
\text { not statistically significant. } \\
\text { The scores of the practical } \\
\text { pathology in dentistry may } \\
\text { be enhanced if the traditional } \\
\text { method is conducted along } \\
\text { with supplementary multimedia } \\
\text { software. }\end{array}$ \\
\hline Sivamalai et al., ${ }^{8} 2011$ & $\begin{array}{l}\text { To investigate } \\
\text { undergraduate medical } \\
\text { students' perceptions of } \\
\text { the benefits and challenges } \\
\text { when digital microscopy } \\
\text { software is combined with } \\
\text { classroom management } \\
\text { software to deliver online } \\
\text { practical pathology } \\
\text { teaching sessions in rurally } \\
\text { orientated medical school. }\end{array}$ & Digital-online website. & $\begin{array}{l}\text { Nearly all medical students } \\
\text { welcomed learning pathology via } \\
\text { online digital technology. }\end{array}$ \\
\hline Samulski et al., ${ }^{9} 2018$ & $\begin{array}{l}\text { To investigate the } \\
\text { effectiveness of adaptive } \\
\text { online modules in teaching } \\
\text { cervical cytopathology. }\end{array}$ & $\begin{array}{l}\text { Adaptive E-Learning modules } \\
\text { (developed using the platform } \\
\text { developed by Smart Sparrow) } \\
\text { that consisted of still images, } \\
\text { basic informative texts, } \\
\text { educational diagrams, and } \\
\text { assessments that guided } \\
\text { students to next learning } \\
\text { concepts or to remedial } \\
\text { didactics. }\end{array}$ & $\begin{array}{l}\text { Learners demonstrated } \\
\text { improvement in their knowledge } \\
\text { after the use of adaptive } \\
\text { E-Learning modules compared } \\
\text { to traditional methods. The } \\
\text { modules were viewed positively } \\
\text { by participants. }\end{array}$ \\
\hline
\end{tabular}


Table 1 continued.

\begin{tabular}{|c|c|c|c|}
\hline Author, year & Purpose of the study & Type of E-learning & Findings \\
\hline Kerfoot et al., ${ }^{10} 2010$ & $\begin{array}{l}\text { To compare knowledge } \\
\text { transfer and retention } \\
\text { between bolus web-based } \\
\text { teaching modules and } \\
\text { online spaced education, a } \\
\text { novel email-based method } \\
\text { of online education founded } \\
\text { on the spacing effect. }\end{array}$ & $\begin{array}{l}\text { Web-based teaching module } \\
\text { containing series of } \mathrm{MCQ} \\
\text { containing a clinical scenario } \\
\text { and histopathology image. }\end{array}$ & $\begin{array}{l}\text { Online spaced education } \\
\text { generates transfer of } \\
\text { histopathology diagnostic skills } \\
\text { and substantially improves their } \\
\text { long-term retention. }\end{array}$ \\
\hline Lee et al.,"1 2015 & $\begin{array}{l}\text { 1) To evaluate the usefulness } \\
\text { of an internet-based system } \\
\text { for the training students } \\
\text { in dermatopathology } \\
\text { using skin diseases with } \\
\text { different prevalence and } \\
\text { complications; and } 2 \text { ) to } \\
\text { evaluate the use of this } \\
\text { system by experts who } \\
\text { are already familiar with } \\
\text { reading conventional } \\
\text { dermatopathological slides. }\end{array}$ & $\begin{array}{l}\text { iSlide, web-based interface } \\
\text { that contained clinical } \\
\text { histories, digitised skin images } \\
\text { (scanned using Aperio digital } \\
\text { slide scanning system) and } \\
\text { interactive dermatopathology. }\end{array}$ & $\begin{array}{l}\text { iSlide system was found to } \\
\text { be a useful tool for learning } \\
\text { dermatopathology. }\end{array}$ \\
\hline $\begin{array}{l}\text { Peacock and Grande, } \\
2016\end{array}$ & $\begin{array}{l}\text { To explore the use of } \\
\text { Google (Alphabet Inc., } \\
\text { Mountain View, California, } \\
\text { USA)-based online app } \\
\text { platform in a 1-year } \\
\text { pathology course at } \\
\text { Mayo Clinic Alix School } \\
\text { of Medicine, Rochester, } \\
\text { Minnesota, USA. }\end{array}$ & $\begin{array}{l}\text { Google Apps on which the } \\
\text { lecture PowerPoints, videos, } \\
\text { pathology slides, collaborative } \\
\text { group learning presentations, } \\
\text { course syllabus, assessments, } \\
\text { and grades can be accessed. }\end{array}$ & $\begin{array}{l}\text { Students found that the } \\
\text { app platform was helpful in } \\
\text { establishing a collaborative, } \\
\text { online classroom environment. }\end{array}$ \\
\hline IJspeert et al.,13 2017 & $\begin{array}{l}\text { To assess the effect of } \\
\text { an E-learning module on } \\
\text { interlaboratory consistency. }\end{array}$ & $\begin{array}{l}\text { Interactive E-learning module } \\
\text { that had histopathological } \\
\text { images. }\end{array}$ & $\begin{array}{l}\text { Variability decreased after } \\
\text { implementation of the E-learning } \\
\text { module. }\end{array}$ \\
\hline Ho et al., ${ }^{14} 2014$ & $\begin{array}{l}\text { To assess the benefits of } \\
\text { online testable concept } \\
\text { maps for learning in } \\
\text { pathology by volunteer } \\
\text { junior medical students. }\end{array}$ & $\begin{array}{l}\text { Online testable pathogenesis } \\
\text { maps are scaffolded } \\
\text { concept maps relating to } \\
\text { disease processes. They } \\
\text { are preconstructed and key } \\
\text { concepts or linking phrases } \\
\text { are removed so that they can } \\
\text { be 'dragged and dropped'. }\end{array}$ & $\begin{array}{l}\text { Online testable pathogenesis } \\
\text { maps are well accepted and can } \\
\text { improve learning of concepts in } \\
\text { pathology by medical students. }\end{array}$ \\
\hline Huang et al.,15 2015 & $\begin{array}{l}\text { 1) To design automatic } \\
\text { classifiers based on } \\
\text { integrated genetic } \\
\text { algorithm and support } \\
\text { vector machine to cluster } 4 \\
\text { different types of cells and } \\
\text { to discriminate dysplasia } \\
\text { from normal cells; } 2 \text { ) To } \\
\text { implement a web-based } \\
\text { cytopathology training and } \\
\text { testing system to increase } \\
\text { learning efficiency of } \\
\text { cytopathologic education. }\end{array}$ & $\begin{array}{l}\text { A web-based } \\
\text { cytopathological training } \\
\text { and testing that has question } \\
\text { bank management, test } \\
\text { management, and online } \\
\text { testing operation functions. }\end{array}$ & $\begin{array}{l}\text { Most of the users agreed the } \\
\text { operation interface is friendly } \\
\text { and easy to use. Users expressed } \\
\text { strong behaviour intention to } \\
\text { further adopt the system. }\end{array}$ \\
\hline
\end{tabular}


Table 1 continued.

\begin{tabular}{|c|c|c|c|}
\hline Author, year & Purpose of the study & Type of E-learning & Findings \\
\hline $\begin{array}{l}\text { Van Dijken et al., }{ }^{16} \\
2008\end{array}$ & $\begin{array}{l}\text { 1) To describe the patient- } \\
\text { based, web-based learning } \\
\text { programme that the authors } \\
\text { created to help students } \\
\text { to better understand } \\
\text { and interpret the clinical } \\
\text { and laboratory findings } \\
\text { associated with disorders } \\
\text { in fluid, electrolyte, and } \\
\text { acid-base homeostasis; 2) } \\
\text { to comment the feedback } \\
\text { of students obtained on } \\
\text { the online, interactive } \\
\text { support of traditional } \\
\text { teaching; } 3 \text { ) to share the } \\
\text { positive experience with } \\
\text { this pedagogical set up and } \\
\text { make freely available the } \\
\text { software developed for all } \\
\text { teachers who would like to } \\
\text { use it. }\end{array}$ & $\begin{array}{l}\text { A web-based learning that } \\
\text { contained clinical history of } \\
\text { patients. }\end{array}$ & $\begin{array}{l}\text { Complementing traditional } \\
\text { lectures with online case-based } \\
\text { studies and interactive group } \\
\text { discussions represents therefore, } \\
\text { a simple means to promote the } \\
\text { learning and the understanding } \\
\text { of complex pathophysiological } \\
\text { mechanisms. }\end{array}$ \\
\hline Desai et al.., 2011 & $\begin{array}{l}\text { To report the preliminary } \\
\text { results of learner } \\
\text { satisfaction using an online } \\
\text { nephropathology teaching } \\
\text { site. }\end{array}$ & $\begin{array}{l}\text { Website that had digitised } \\
\text { kidney biopsy specimen } \\
\text { with a description of key } \\
\text { pathological findings and final } \\
\text { diagnosis. }\end{array}$ & $\begin{array}{l}\text { Nephrology on-demand } \\
\text { histopathology is a well-received } \\
\text { teaching tool to learners of all } \\
\text { training levels. }\end{array}$ \\
\hline Abdollahi et al., ${ }^{18} 2014$ & $\begin{array}{l}\text { To assess the effect of a } \\
\text { web-based educational } \\
\text { course on the concordance } \\
\text { rate among the Gleason } \\
\text { Score reports of } \\
\text { pathologists from selected } \\
\text { hospitals of Tehran } \\
\text { University of Medical } \\
\text { Sciences, Tehran, Iran. }\end{array}$ & $\begin{array}{l}\text { Web-based course with } \\
\text { photos and course materials. }\end{array}$ & $\begin{array}{l}\text { Through web-based education, } \\
\text { pathologists can exchange } \\
\text { views and contribute to the rise } \\
\text { in the level of reproducibility. } \\
\text { Such training courses are } \\
\text { strongly recommended for } \\
\text { significant pathological issues } \\
\text { including the grading of prostate } \\
\text { adenocarcinoma. }\end{array}$ \\
\hline Bijol et al.., ${ }^{19} 2015$ & $\begin{array}{l}\text { To assess the difference in } \\
\text { final exam performances } \\
\text { on quizzed and non- } \\
\text { quizzed materials as well as } \\
\text { differences in performances } \\
\text { between students who did } \\
\text { and did not use the quizzes. }\end{array}$ & $\begin{array}{l}\text { Website: Articulate Quizmaker } \\
\text { 13. Interactive features such } \\
\text { as hot spots, MCQ, drag and } \\
\text { drop, and mix and match. } \\
\text { Feedback explanation of the } \\
\text { answers to the questions. }\end{array}$ & $\begin{array}{l}\text { Adding interactive online } \\
\text { formative assessments improved } \\
\text { students' learning experience } \\
\text { overall. }\end{array}$ \\
\hline Jurjus et al., ${ }^{20} 2018$ & $\begin{array}{l}\text { To develop and pilot } \\
\text { MAPA and to test the } \\
\text { hypothesis that principles } \\
\text { of E-learning, applied to an } \\
\text { integrated microanatomy } \\
\text { and pathology laboratory in } \\
\text { a modular based curriculum } \\
\text { would improve medical } \\
\text { student satisfaction and } \\
\text { perceived learning of the } \\
\text { material. }\end{array}$ & Online, self-directed learning. & $\begin{array}{l}\text { MAPA has been perceived by } \\
\text { medical students as a helpful, } \\
\text { web-based, and self-selected } \\
\text { adjunct for learning. }\end{array}$ \\
\hline
\end{tabular}




\begin{tabular}{|c|c|c|c|}
\hline Author, year & Purpose of the study & Type of E-learning & Findings \\
\hline Engelberg et al.., 2015 & $\begin{array}{l}\text { To document and reduce } \\
\text { interobserver variation } \\
\text { of ER, PR, Ki-67, and } \\
\text { HER2 scores among the } \\
\text { pathologists participating } \\
\text { in the Athena pathology } \\
\text { harmonisation projects; } \\
\text { 2) to document how } \\
\text { pathologists perform on } \\
\text { biomarker scoring and } \\
\text { assessing 'Score the Core' } \\
\text { as a training tool; } 3 \text { ) to } \\
\text { improve the precision and } \\
\text { accuracy of assessing } \\
\text { breast cancer biomarkers: } \\
\text { ER, PR, Ki-67, and HER2 } \\
\text { (IHC4). }\end{array}$ & $\begin{array}{l}\text { Online training tool with } \\
\text { digitised whole slide images. }\end{array}$ & $\begin{array}{l}\text { The online training tool can serve } \\
\text { as an important component } \\
\text { of ongoing quality assessment } \\
\text { and can improve the accuracy } \\
\text { of breast cancer prognostic } \\
\text { biomarkers. }\end{array}$ \\
\hline
\end{tabular}

ER: oestrogen receptor; HER2: human epidermal growth factor receptor 2; IHC4: immunohistochemical 4; MAPA: Microanatomy and Pathology Atlas; MCQ: multiple choice questions; PR: progesterone receptor.

\section{Purpose of Incorporating E-Learning in Pathology Education}

Current evidence indicates that E-learning has been incorporated in pathology education in both classroom and clinical settings. In dental, medical, and resident classroom settings, E-learning has been used to determine the effectiveness of blended learning (combining E-learning with traditional learning methods) compared to traditional learning in histopathology education; ${ }^{5}$ examine the efficiency of using educational software in practical oral pathology scores; ${ }^{7}$ evaluate the usefulness of an internetbased system in learning dermatopathology;"11 explore the use of Google (Alphabet Inc., Mountain View, California, USA)-based online app platform in teaching pathology course;12 evaluate both the qualitative and quantitative impact of online testable pathogenesis maps on learning pathology; ${ }^{14}$ explore the educational value of web-based formative assessment tool for renal pathology, and develop and pilot an Microanatomy and Pathology Atlas (MAPA) for medical students; ${ }^{20}$ investigate perceptions of digital microscopy software when combined with classroom management software to deliver online practical pathology teaching sessions; ${ }^{8}$ compare the knowledge transfer and retention between bolus web-based teaching modules and online spaced education; ${ }^{10}$ investigate the effectiveness of adaptive online modules in teaching cervical cytopathology; ${ }^{9}$ and collect students' feedback on an online, interactive support of traditional teaching of pathophysiology. ${ }^{16}$

In clinical settings, E-learning has been used to assess the intra and interobserver concordance rates in the Gleason scoring of prostatic adenocarcinoma, before and after a web-based educational course among the pathologists; ${ }^{18}$ evaluate the performances of pathologists on using a web-based pathologist training tool;21 implement a web-based cytopathology training and testing system; ${ }^{15}$ and assess the interlaboratory consistency in the histopathological diagnosis. ${ }^{13}$ In addition, E-learning has been used to analyse the usage of web-based pathology practice examinations ${ }^{6}$ and gather learner satisfaction of web-based teaching modules in nephropathology education. ${ }^{17}$

\section{Incorporation of E-Learning in Pathology Education}

In the articles reviewed, E-learning has been incorporated as a) quizzes on the website, such 
as a series of multiple choice questions (MCQ) containing a clinical scenario and histopathology image; 10 b) course materials with photos on websites:18 c) digitised images on websites and pathological findings and diagnosis;,82,17 d) digitised images with text descriptions, clinical histories, and self-assessments with feedback on websites;11,6 e) course materials with online practical and lecture notes, and digitised slide images with interactive microscopy section for the students to review materials and selfevaluate on the website; 5 f) CD-ROM with images of pathology samples put in appropriate arrangements; $^{7}$ g) Google apps through which the lecture PowerPoints, videos, pathology slides, collaborative group learning presentations, course syllabus, assessments, and grades can be accessed; ${ }^{12}$ h) E-learning modules developed using special software that consist of images, informative texts, educational diagrams, assessments that guide students to the next learning concepts or to remedial didactics, interactive features such as hot spots, $M C Q$, drag and drop, mix and match, and feedback explanations of the answers to the questions; and finally, $, 13,19$ i) online testable pathogenesis maps that are scaffolded concept maps relating to disease processes. ${ }^{14}$

\section{Outcome Measures}

In the reviewed articles, the outcome measures that were used to evaluate the effects of E-learning in pathology education were retention skills, long-term learning efficiencies of online educational methodologies, resident performances on spaced education versus webbased teaching, student perceptions, pre versus post-scores, and only post-scores. ${ }^{5-21}$

In general, from the studies reviewed, students welcomed the addition of learning pathology via digital technology. ${ }^{8}$ They found the app platform helpful in establishing a collaborative, online classroom environment. ${ }^{12}$ They favoured online testable pathogenesis maps, ${ }^{14}$ supported further adoption of the online system because it was useful in cytopathology diagnosis and training, ${ }^{15}$ and they found that online quizzes improved learning experience. ${ }^{19}$ Very few studies that compared the pre and post-scores showed that post-scores improved after using E-learning tools. ${ }^{9,13,21}$ Studies that focussed on only the post- scores found that the scores of the students who used the E-learning tools were higher than the students who did not use the E-learning tools. $5,7,14,19$

The following common survey statement topics received positive responses in the reviewed articles: helpful annotations, easy access from anywhere, more convenient for learning, faster than using microscopes, allows self-paced learning, everyone sees the same image, better for group learning, better technology, feedback received was helpful in reinforcing concepts, module was effective in presenting the content and concepts, more engaging than the lecture and texts, online learning was a worthwhile adjunct to training, recommend to my classmates, collaborative capabilities to create joint-projects were helpful, enhanced learning, and improved understanding and identification of the differences between normal tissues and those with pathologies. .,9,1,14,20 $^{2}$ Some difficulties participants indicated when using the online methods of learning included a lack of practice with a microscope, less interaction with the teacher while on rural placement, problems with the internet connection, technical problems with online technology, user needs of computer skills, among others. ${ }^{8}$ In the open comments, students also indicated that they found the interactive aspects of E-learning very interesting and engaging: it yielded more impact than just reading about a topic; it could be done at the student's own pace and they could start and stop at will;'; it was easier to visualise; and was clearly organised and labelled. ${ }^{20}$ Students also suggested some improvements to future E-learning modules, such as user interface; more information; integration with other disciplines; more quiz features, pictures, tissue samples, and short explanations; consistency in the presentation of the material; comprehensive test features; and magnification features. . $^{14,20}$

\section{DISCUSSION}

The primary objective of this paper was to identify the approaches to measure the objective outcomes of students' learning influenced by E-learning modules in pathology education.

Out of 17 articles reviewed, this study identified 2 articles that used pre versus post-scores to measure the participants' performance in clinical settings, and 1 article in an educational 
setting. ${ }^{9}$ The study, which was conducted in an educational setting using a randomised, mixed methods, crossover design, reported improved post-test scores of the participants. Even though this method would be an ideal approach to measure the objective outcomes of the CT students, unlike this study which had a total of 36 participants, the present author's CT programme has 4-12 students per year. Therefore, it is always a challenge to show statistically significant results with fewer student participants. A collaborative approach with other CT programmes to increase the sample size would help measure the students' objective outcomes and achieve significance.

The secondary objectives of this study were to provide a narrative review of the approaches used in incorporating E-learning in pathology education and to provide a faculty member's perspective of experiences and lessons learned in developing E-learning modules and suggestions for future faculty developers of E-learning modules.

Based on the reviewed articles, it is evident that E-learning has been incorporated and evaluated successfully in pathology for variety of purposes. Students' perception surveys predominated as an outcome measure than the cost effectiveness of the E-learning modules or the test scores, particularly, the pre versus post-test scores.

Many of the articles reviewed used either digitised whole slide images or pathology images with quiz materials as E-learning tools. A limited number of studies used E-learning as a module that included lecture materials, videos, pathology images, and interactive features such as hot spots, $M C Q$, drag and drop, and mix and match, with feedback explanation of the answers to the questions. In the author's experience in cytopathology education, students enjoyed and benefited from similar E-learning modules with videos that had voiceover descriptions and interactive self-assessment features. ${ }^{4}$ Additionally, the reviewed articles lacked detailed explanation in regard to the time and cost involved in developing the E-learning modules. In the author's experience, time and cost are critical issues to consider for the faculty members in developing E-learning modules.

The anticipated faculty time commitment exceeded 50\% when the author developed their first E-learning module (12 minutes 23 seconds in length) in their programme. This was primarily to learn the various E-learning technologies and software available and to choose those that best fit the objective. By the time the optimal option was chosen, affordable software that fit the objective of the module, and learned to develop the E-learning module, updated software programmes were already available to consider for the next E-learning modules. Therefore, faculty members need to be aware of the constant changes and updates in the technologies and the software and plan to spend considerable time to learn these technologies.

Updating educational material is a critical process in training healthcare professionals. A faculty member needs to be aware of the considerable amount of time spent in this process to make the most of the E-learning modules for education. From a faculty point of view, the author found updating E-learning modules initially challenging, particularly videos that contained digital images and voiceover audio descriptions. For example, when a description in an existing video portion of the E-learning module needed to be included, the whole video then had to be reshot, edited, inserted in the module, and republished to acquire the URL. This led to the rearrangement of the whole E-learning module.

A time-saving strategy identified through experience in developing E-learning modules was to involve the students. The author's institution provided yearly funding opportunities for facultyled E-learning projects, in which the students help the faculty members develop these modules. From this experience, working with students also helped the author to understand what they would like to see and how they would use the module. Their innovative ideas made the modules more creative and interactive. All of the E-learning modules were developed through internal funding mechanisms. As the process unfolded, unanticipated costs were identified. For the initial E-learning modules developed in the programme, the biggest expenditure was a professional videographer, voiceover recording, and editing of the videoclips. For the later modules, the author's institution created an E-learning Lab that provided high quality video cameras in addition to a soundproof booth in which the audio recording could be done for the E-learning modules. This reduced expenses considerably. 
A limitation of this study was the small number of articles reviewed. A more systematic approach on searching and selection of articles to review could have identified more information on using E-learning modules in pathology education.

In summary, the task of developing and evaluating E-learning modules may seem difficult; however, with proper planning and commitment it is achievable. As a faculty member who developed and evaluated E-learning modules in this CT programme, it gives the author great satisfaction and encouragement to observe students enjoy and benefit from these modules. Therefore, the author highly recommends that faculty members of other educational programmes who have never had the opportunity develop this valuable resource to enhance their training in their educational programme. One way to sustain the inclusion of E-learning in pathology is to collaborate with other educational programmes to develop E-learning modules so they can be shared among programmes. Through this, the time and manpower can be shared and the content of the modules can be standardised. Involving students, residents, or fellows in the development of E-learning modules with the faculty members to capture students and faculty members perspectives can also be considered to improve the quality of E-learning modules.

\section{CONCLUSIONS}

E-learning has been widely used in pathology education. There is still, however, a lack of studies that evaluate the cost effectiveness of the E-learning technologies, and pre and post-test scores of the participants.

\section{References}

1. Park JY et al. Effects of blended cardiopulmonary resuscitation and defibrillation e-learning on nursing students' self-efficacy, problem solving, and psychomotor skills. Comput Inform Nurs. 2016;34(6):27280.

2. Pinto $A$ et al. E-learning and education in radiology. Eur $\mathrm{J}$ Radiol. 2011;78(3):368-71.

3. Donnelly $A D$ et al. Virtual microscopy in cytotechnology education: Application of knowledge from virtual to glass. Cytojournal. 2012;9:12.

4. Mukherjee MS, Donnelly AD. Initial assessments of e-learning modules in cytotechnology education. J Pathol Inform. 2018;9:4.

5. Ariana $A$ et al. Integration of traditional and e-learning methods to improve learning outcomes for dental students in histopathology. J Dent Educ. 2016;80(9):1140-8.

6. Klatt EC. Web-based pathology practice examination usage. J Pathol Inform. 2014;5(1):34

7. Hosseini SV et al. Using e-learning in teaching the quality of the practical oral pathology on dentistry students. Res Dev Med Educ. 2014;3(1):61-5.

8. Sivamalai $\mathrm{S}$ et al. Teaching pathology via online digital microscopy: Positive learning outcomes for rurally based medical students. Aust J Rural Health.

\section{1;19(1):45-51.}

9. Samulski TD et al. The utility of adaptive eLearning in cervical cytopathology education. Cancer Cytopathol. 2018;126(2):129-35.

10. Kerfoot BP et al. Online spaced education generates transfer and improves long-term retention of diagnostic skills: A randomized controlled trial. J Am Coll Surg. 2010;211(3):331-7.e1.

11. Lee $P$ et al. islide: A 'big picture' interactive teledermatopathology e-learning system. Br J Dermatol. 2015;172(3):692-9.

12. Peacock JG, Grande JP. An online app platform enhances collaborative medical student group learning and classroom management. Med Teach. 2016;38(2):174-80.

13. IJspeert JE et al. Implementation of an e-learning module improves consistency in the histopathological diagnosis of sessile serrated lesions within a nationwide population screening programme. Histopathology. 2017;70(6):929-37.

14. Ho $\vee$ et al. Online testable concept maps: Benefits for learning about the pathogenesis of disease. Med Educ. 2014;48(7):687-97.

15. Huang PC et al. Design and evaluation of cervical pap smear e-learning system for the education of cytopathology. Appl Math Inf Sci. 2015;9(2L):617-26.

16. Van Dijken PC et al. Evaluation of an online, case-based interactive approach to teaching pathophysiology. Med Teach. 2008;30(5):e131-6.

17. Desai T et al. Web-based nephropathology teaching modules and user satisfaction: The nephrology on-demand experience. Ren Fail. 2011;33(10):1046-8.

18. Abdollahi A et al. Inter-observer reproducibility before and after web-based education in the Gleason grading of the prostate adenocarcinoma among the Iranian pathologists. Acta Med Iran. 2014;52(5):370-4.

19. Bijol $\vee$ et al. Medical student webbased formative assessment tool for renal pathology. Med Educ Online. 2015;20:26765

20. Jurjus RA et al. Design of an online histology and pathology atlas for medical students: An instructional aid to self-directed learning. Medical Science Educator. 2018;28(1):101-10.

21. Engelberg JA et al. "Score the core" web-based pathologist training tool improves the accuracy of breast cancer IHC4 scoring. Hum Pathol. 2015;46(11):1694-704. 